\title{
Study Of Domestic E-Waste Management in Sungguminasa City, Gowa Regency, South Sulawesi Province, Indonesia
}

\author{
Irwan Ridwan Rahim ${ }^{1, *}$, Rusdi Usman Latif ${ }^{1}$, and Syahiq Mahzuz Umar $^{2}$ \\ ${ }^{1}$ Environmental Engineering, Faculty of Engineering, Hasanuddin University, Makassar - Indonesia \\ ${ }^{2}$ Graduate Program of Environmental Engineering, Faculty of Engineering, Hasanuddin University, Makassar - \\ Indonesia
}

\begin{abstract}
E-waste is the impact resulting from the massive use of electronic goods in the information technology era. The increasing use of electronic goods resulted in increasing electronic waste.

This study aims to calculate the potential of generation and characteristics of e-waste, processing methods and potential economic value of electronic e-waste recycling in Sungguminasa City, Gowa Regency, South Sulawesi Province, Indonesia. The study was conducted in 14 sub-districts in Somba Opu district, the largest population district in Sungguminasa City with population of 157,448 people or about $1.67 \%$ of the population of South Sulawesi Province.

The research method is conducted by analyzing the data obtained through: survey, observation and interview to the head of household in Somba Opu District, household divided in 3 groups by monthly income level (high, medium and low) and obtained: ewaste characteristics, waste generation potential, processing method and potential economic value of recycled e- waste.

The analysis results of 37 types of electronic goods, 3 types of electronic goods with the largest percentage are: televisions, refrigerators, personal computers, namely: $26 \%$, and $17 \%, 14 \%$ or respectively: 150,98 , and 80 units/year. The potential of e-waste generation in Somba Opu District: 801,8 ton/year. The traditional method of e-waste processing is "converted function" by $55 \%$ and then "repaired" by $19 \%$ and "stored" by $17 \%$, while the least applied e-waste method is "discarded" with a percentage of $9 \%$. The results of the economic potential analysis of e-waste recycling of the 3 largest electronic goods are: refrigerator US\$ 32,439, computer US\$ 45,994 and television US\$ 76,254 (US\$ 1,00= IDR 14,000)
\end{abstract}

Keywords: electronic; waste; management.

\section{Introduction}

Electronic waste belongs to the category of B3 waste. Electronic waste is classified as hazardous waste from specific sources with waste code, namely D219 with pollutant sources, namely from manufacturing and assembling electronic equipment components.These ingredients and used spare parts for various gadgets are B3 waste because the components of electronic goods are composed of hazardous components, namely the fractions in the form of iron, copper, aluminum, gold and other heavy metals whose levels exceed $60 \%$. The increasing use of gadgets and electronic equipment that are increasingly advanced among the world community will trigger an increase in the amount of electronic waste.Electronic waste is electronic equipment that cannot be used anymore and is disposed of like computer devices, mobile phones that are in abundance due to short usage time.The society's consumptive attitude towards the use of electronic goods results in an increase in the amount of electronic waste produced.The increasing use of electronic equipment has the potential to cause greater electronic waste. Electronic waste can be categorized as hazardous waste if it has one of the properties such as flammable, corrosive, reactive, and toxic or derived from household activities, containing materials and/or packaging of a type of hazardous and/or toxic material resulting from its nature or concentration and or the amount, both directly and indirectly can damage and or pollute the environment and endanger human health $[1,3]$. The management of hazardous waste that is good and true in the community is an urgent need. Government regulations and policies for managing all types of waste, especially household hazardous waste are important matters, but generally the community has not implemented hazardous waste management in

* Corresponding author: irwanrr@yahoo.com 
accordance with applicable regulations so that the possibility of a negative impact on the environment [13]

Gowa Regency is one of the districts located in the South Sulawesi Province, which has a capital city in Somba Opu District and is also one of the second largest regions after Makassar City in South Sulawesi Province, based on data from the Central Statistics Agency of South Sulawesi Province, known in 2014 as 652,941, or around $8.41 \%$ of the total population of the Province of South Sulawesi as show in table 1., which resulted in the growth and development of activities in Gowa Regency increased so that there were several problems, one of which was from the aspect of solid waste, namely the increasing volume of waste produced every day.

\section{Material and Method}

The research method is conducted by analyzing the data obtained through: survey, observation and interview to 100 head of household in Somba Opu District, household divided in 3 groups by monthly income level (high, medium and low) as show in table 2. and obtained: e-waste characteristics, waste generation potential, processing method and potential economic value of recycled e- waste.

Table 1. Gowa Regency Population

\begin{tabular}{|r|l|r|r|}
\hline No. & \multicolumn{1}{|c|}{ Village } & Population & $\begin{array}{c}\text { Family } \\
\text { Population }\end{array}$ \\
\hline 1 & Pandang-pandang & 8,678 & 1.739 \\
\hline 2 & Sungguminasa & 8,663 & 1,736 \\
\hline 3 & Batangkaluku & 15,564 & 3,113 \\
\hline 4 & Kalegowa & 2,891 & 569 \\
\hline 5 & Bontoramba & 4,857 & 973 \\
\hline 6 & Mawang & 5,473 & 1,076 \\
\hline 7 & Romangpolong & 7,942 & 1,591 \\
\hline 8 & Bonto-bontoa & 14,556 & 2,917 \\
\hline 9 & Tamarunang & 14,692 & 2,944 \\
\hline 10 & Katangka & 11,842 & 2,373 \\
\hline 11 & Tombolo & 16,978 & 3,402 \\
\hline 12 & Paccinongan & 24.049 & 4,819 \\
\hline 13 & Samata & 8,381 & 1,679 \\
\hline 14 & Tompobalang & 12,882 & 2,581 \\
\hline & TOTAL & 157,448 & 31,512 \\
\hline
\end{tabular}

Table 2. Groups by monthly income level.

\begin{tabular}{|l|c|c|}
\hline Group Salary & Salary Range (US\$) & Sample Amount \\
\hline High & $>321$ & 100 \\
\hline Medium & $179-321$ & 100 \\
\hline Low & $<179$ & 100 \\
\hline
\end{tabular}

Calculating the Potential of E-Waste emergence for each village using the equation from Chung, et al (2011) as follows:

$$
E=\frac{w x N}{Z}
$$

$\mathrm{E}=$ Estimated amount of E-Waste generated $(\mathrm{kg} / \mathrm{y})$

$\mathrm{W}=$ Weight of electronic product $(\mathrm{kg})$

$\mathrm{N}=$ Number of electronic units (units)

$\mathrm{L}=$ Operational life time (year)

Calculating the potential for E-Waste per capita generation, using the following equation:

$$
\text { E. Capita }=\frac{E}{P}
$$

Where,

E.Capita = Average amount of E-Waste generated per capita in a year $(\mathrm{kg} / \mathrm{y})$

$\mathrm{E}=$ Estimated amount of E-Waste generated $(\mathrm{kg} / \mathrm{y})$

$\mathrm{P}=$ Population

\section{Result and Discussion}

Based on survey results of 300 respondents obtained 37 types of electronic goods which are generally owned by families in Sungguminasa city, there are 14 types of electronic goods owned by almost all families, 3 types of electronic goods with the largest number are: Energy saving lamps (2340), Cellphones (1092) and Fan (651), and 3 types of electronic goods with the smallest number are: Drinking water dispensers (273), Home mixers (217) and Home Printer (210), as shown in Fig.2.

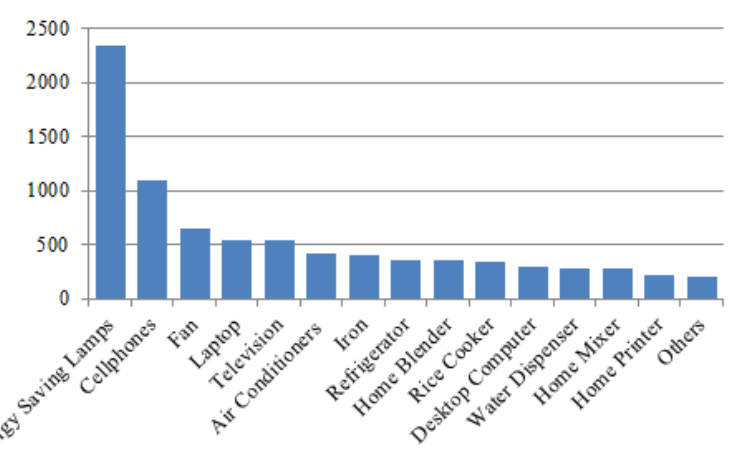

Fig.2 Amount of electronic goods from 300 respondents

\subsection{The Average Potential of Electronic Waste generation for each person based on income level}

The average potential of electronic waste produced by each person based on the category per year can be seen in Table 3. Based on Table 1, the average potential of electronic waste produced by each person by category is different. This turns out that one of them is influenced by one's economic level. The higher one's income, the greater the potential for electronic waste produced

Table 3. Potential of Electronic Waste generation for each person based on income level.

Where, 


\begin{tabular}{|c|c|c|c|c|c|}
\hline & \multirow{2}{*}{$\begin{array}{l}\text { Electronic } \\
\text { Goods }\end{array}$} & \multirow{2}{*}{$\begin{array}{c}\text { Average } \\
\text { Weight } \\
(\mathrm{kg})\end{array}$} & \multicolumn{3}{|c|}{$\begin{array}{c}\text { Waste Generation } \\
(\mathrm{kg} / \mathrm{person} / \mathrm{y})\end{array}$} \\
\hline & & & High & Medium & Low \\
\hline 1 & $\begin{array}{l}\text { Energy Saving } \\
\text { Lamps }\end{array}$ & 0.02 & 0.02 & 0.01 & 0.004 \\
\hline 2 & Cellphones & 0.50 & 0.30 & 0.30 & 0.30 \\
\hline 3 & Fan & 10.00 & 2.10 & 2.00 & 2.10 \\
\hline 4 & Laptop & 3.50 & 1.20 & 0.90 & 0.80 \\
\hline 5 & Television & 36.20 & 8.50 & 5.60 & 4.70 \\
\hline 6 & $\begin{array}{l}\text { Air } \\
\text { Conditioners }\end{array}$ & 18.50 & 1.90 & 3.30 & 0.70 \\
\hline 7 & Iron & 1.10 & 0.10 & 0.10 & 0.09 \\
\hline 8 & Refrigerator & 48.00 & 5.70 & 5.30 & 2.40 \\
\hline 9 & Home Blender & 2.23 & 0.20 & 0.20 & 0.20 \\
\hline 10 & Rice Cooker & 4.70 & 0.20 & 0.10 & 0.20 \\
\hline 11 & $\begin{array}{l}\text { Desktop } \\
\text { Computer }\end{array}$ & 29.60 & 5.92 & 4.10 & 1.70 \\
\hline 12 & $\begin{array}{l}\text { Water } \\
\text { Dispenser }\end{array}$ & 15.50 & 2.50 & 1.60 & 2.00 \\
\hline 13 & Home Mixer & 1.20 & 0.20 & 0.08 & 0.01 \\
\hline 14 & Home Printer & 6.51 & 1.04 & 0.80 & 0.80 \\
\hline 15 & $\begin{array}{l}\text { Washing } \\
\text { Machine }\end{array}$ & 60.11 & 2.70 & 2.20 & 2.40 \\
\hline 16 & Frezer & 35.10 & 0.80 & 0.50 & 0.00 \\
\hline 17 & Microwaves & 15.00 & 1.10 & 0.30 & 0.00 \\
\hline 18 & Hair Drayer & 1.40 & 0.07 & 0.03 & 0.02 \\
\hline 19 & $\begin{array}{l}\text { Vacuum } \\
\text { Cleaner }\end{array}$ & 8.45 & 0.30 & 0.03 & 0.00 \\
\hline 20 & Grill & 1.32 & 0.06 & 0.05 & 0.01 \\
\hline 21 & $\begin{array}{l}\text { Internet } \\
\text { Modem }\end{array}$ & 0.65 & 0.06 & 0.03 & 0.01 \\
\hline 22 & Telephone & 2.51 & 0.09 & 0.07 & 0.01 \\
\hline 23 & $\begin{array}{l}\text { Fotocopy } \\
\text { Machine }\end{array}$ & 70.10 & 0.00 & 0.02 & 0.00 \\
\hline 24 & Radio & 2.70 & 0.05 & 0.10 & 0.04 \\
\hline 25 & $\begin{array}{l}\text { Pocket } \\
\text { Camera }\end{array}$ & 1.60 & 0.10 & 0.05 & 0.04 \\
\hline 26 & $\begin{array}{l}\text { Video } \\
\text { Recorder }\end{array}$ & 5.12 & 0.00 & 0.02 & 0.00 \\
\hline 27 & $\begin{array}{l}\text { Sound } \\
\text { Recorder }\end{array}$ & 1.90 & 0.00 & 0.03 & 0.00 \\
\hline 28 & $\begin{array}{l}\text { Audio } \\
\text { Amplifier }\end{array}$ & 2.87 & 0.03 & 0.03 & 0.03 \\
\hline 29 & Music Tools & 3.17 & 0.40 & 0.10 & 0.10 \\
\hline 30 & Video Game & 1.14 & 0.04 & 0.01 & 0.01 \\
\hline 31 & $\begin{array}{l}\text { Fluorescent } \\
\text { Lamps }\end{array}$ & 0.12 & 0.80 & 0.30 & 0.10 \\
\hline 32 & $\begin{array}{l}\text { Charger } \\
\text { Lamps }\end{array}$ & 0.57 & 0.07 & 0.03 & 0.04 \\
\hline 33 & Electric Drill & 4.17 & 0.07 & 0.01 & 0.03 \\
\hline 34 & Electric Saw & 2.01 & 0.02 & 0.00 & 0.00 \\
\hline 35 & $\begin{array}{l}\text { Sewing } \\
\text { Machine }\end{array}$ & 7.13 & 0.00 & 0.07 & 0.05 \\
\hline 36 & Solder & 0.71 & 0.01 & 0.02 & 0.01 \\
\hline 37 & $\begin{array}{l}\text { Incandescent } \\
\text { Lamps }\end{array}$ & 0.23 & 0.05 & 0.03 & 0.02 \\
\hline
\end{tabular}

\section{Conclussion}

1. The identification of 37 types of electronic equipment owned by families in Somba Opu District, Gowa in the form of percent are: energy saving lamps $78 \%$, mobile phones $52 \%$, fans $31 \%$, laptop $26 \%$, air conditioner $20 \%$, ironing $19 \%$, and blenders $17 \%$, rice cookers $16 \%$, dispensers and mixers $13 \%$, printers $11 \%$ and others $10 \%$, especially refrigerators, computers and televisions with percentages of $17 \%, 14 \%$ and $26 \%$ respectively. With the number of units per year, 98, 80 and 150 units / year respectively. The potential for e-waste generation in the Somba Opu District as a whole was obtained from 14 villages at $801,838.9 \mathrm{~kg} /$ year or 801.8 tons / year. 2 . The e-waste management method that is commonly found in the form of percent is the conversion of e-waste to be reused by $55 \%$ and then repaired by $19 \%$ and stored as a decoration by $17 \%$, while the least management method is found is dumped with landfill percentage of $9 \%$. 3. The emergence of e-waste obtained from 3 electronic items (refrigerators, computers and televisions) has great economic value potential by recycling the e-waste component. The results of a potential analysis of the economic value of e-waste recycling from 3 electronic equipment are: a refrigerator Rp. 1,657,807, - computer Rp. 2,327,121, - and television Rp. 3,625,178, -

\section{References}

1. Alumur, S dan Kara, B.. "A New model for The Hazardous Waste Location Routing Problem". Computers and Operations Research 34, 1406-1423 (2007)

2. Anonim. 1999. Peraturan Pemerintah No. 85 tentang perubahan atas Peraturan Pemerintah No.18 tentang pengelolaan limbah bahan berbahaya dan beracun. Jakarta : Presiden Republik Indonesia.

3. Badan Standarisasi Nasional. 1994. Metode Pengambilan dan Pengukuran Contoh Timbulan dan Komposisi Sampah Perkotaan. SNI 19-3694-1994.

4. Chung, S., Lau, K., dan Zhang, C. 2011. Generation of and control measure for e-waste in Hongkong. Waste Management . 31, 544-554.

5. Cui, J. dan Zhang, L. 2008. Metallurgical recovery of metals from electronic waste : A review. Journal of Hazardouse Materials. 158, 228-256.

6. Darby, L. dan Obara, L. 2005. Household recycling behaviour and attitutes towards the disposal of smalll electrical and electronic equipment. Resource, Conversation and Recycling. 44, 17-35.

7. Ongondo, F.O., Williams, I.D., dan Cherrett, T.J. 2011. How are WEEE doing? A global review of the management of electrical and electronic wastes. Waste Management. 31, 714-730.

8. Robinson, B.H. 2009. E-Waste : An assessment of global production and environmental impacts. Science of the Total Environmment. 408, 183-191. 
9. Sinha-Khetriwal, D., Kraeuchi, P., dan Schwaninger, M. 2005. A comparison of electronic waste recycling in switzerland and in India. 25, 492504.

10. Streicher-Porte, M., Widmer, R., Jain, A., Bader, H.P., Sceidegger, R., dan Kytzia, S. 2005. Key drivers of the e-waste recycling system : Assesing and modelling e-waste processing in the informal sector in delhi. Environmental Impact Assesment. 25, 472-491.

11. Widmer, R., Oswald-Krapf, H., Sinha-Khetriwal, D., Schanellmann, M., dan Boni, H. 2005. Global perspective on e-waste. Environmental Impact Assesment. 25, 436-458.
12. Widyarsana, I.M.W., Winardy, D., Damanhuri, E., dan Padmi, T. 2010. Identifikasi material E-waste komputer dan komponen daur ulangnya di lokasi pengepulan E-waste (Studi kasus : Kota Bandung). Surabaya.

13. Yong Kang, H. dan Schoenung, J.M. 2005. Electronic waste recycling: A review of U.S. Infrastucture and Technology Options. 45, 368-400.

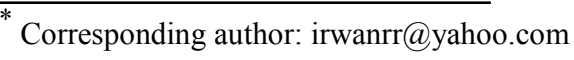

